\title{
Toward sustainable hydrogen storage and carbon dioxide capture in post- combustion conditions
}

\author{
Mariem Moussa $^{\mathrm{a}}$, Najoua Bader ${ }^{\mathrm{a}}$, Nausika Querejeta ${ }^{\mathrm{b}}$, Inés Durán ${ }^{\mathrm{b}}$, Covadonga Pevida $^{\mathrm{b}}$, and \\ Abdelmottaleb Ouederni ${ }^{\mathrm{a}}$ \\ ${ }^{a}$ Research Laboratory: Process Engineering and Industrials Systems, National School of \\ Engineers of Gabes, University of Gabes, St. Omar Ibn Khattab, 6029 Gabes, Tunisia \\ meriouma.moussa@gmail.com, najoua.bader@gmail.com, mottaleb.ouederni@enig.rnu.tn \\ b Instituto Nacional del Carbón, INCAR-CSIC, Apartado 73, 33080 Oviedo, Spain
}

\begin{abstract}
This work addresses two environmental issues of major concern: hydrogen storage for hydrogen economy implementation and $\mathrm{CO}_{2}$ capture to reduce greenhouse gas emissions. For these purposes, two granular activated carbons were synthesized through chemical activation of olive stones by means of potassium derivatives ( $\mathrm{KOH}$ and $\mathrm{K}_{2} \mathrm{CO}_{3}$ ). The storage or capture technique is pure physical adsorption on the porous framework of carbon materials. The porosity characterizations reveal typical ultramicroporous carbons with average pore sizes of about 0.53 and $0.69 \mathrm{~nm}$ for $\mathrm{K}_{2} \mathrm{CO}_{3}$ and $\mathrm{KOH}$-activated carbons, respectively. The volumetric measurements of cryogenic hydrogen adsorption show monolayer process. At subatmospheric pressures the narrower micropores show stronger binding energy to hydrogen molecules. Consequently, $\mathrm{K}_{2} \mathrm{CO}_{3}$-activated carbon outperforms the other sample at pressures lower or equal to 100 Torr. However, at higher pressures this porosity range saturates and $\mathrm{KOH}$-activated carbon exhibits a $\mathrm{H}_{2}$ storage capacity of $3 w t \%, 70 \%$ of which is achievable at only 1 bar. This result is interesting especially for stationary applications wherein volume is not a limitation. $\mathrm{CO}_{2}$ shows a similar behavior than $\mathrm{H}_{2}$ when it was adsorbed purely at $\mathrm{O}^{\circ} \mathrm{C}$, and $\mathrm{AC}_{-} \mathrm{KOH}$ retains its excellence with a capacity of $5.6 \mathrm{mmol} \mathrm{g}^{-1}$ at 1 bar. Finally, the two carbons were tested as $\mathrm{CO}_{2}$ adsorbents in conditions representative of post combustion capture applications $\left(10 \% \mathrm{CO}_{2}\right.$ at atmospheric pressure and at $\left.50^{\circ} \mathrm{C}\right)$. Both carbons show
\end{abstract}


fast adsorption-desorption kinetics, perfectly described by pseudo-first order model. At these conditions, it was proven that only narrow micropores are essential for $\mathrm{CO}_{2}$ adsorption.

Keywords: $\mathrm{H}_{2}$ storage, $\mathrm{CO}_{2}$ capture, activated carbons, olive stones, adsorption, narrow micropores

\section{Introduction}

Nowadays, energy is basically generated from the combustion of the limited fossil fuels. Therefore, the volume of the emitted greenhouse gases is in continual increase. In 2014, the $\mathrm{CO}_{2}$ concentrations in ambient air approached 400 part per million (ppm) and it increased by 120 ppm from the $\mathrm{CO}_{2}$ concentrations in the pre-industrial time [1]. In 2005, the Kyoto protocol has been enforced, and it has been reported that the $\mathrm{CO}_{2}$ emissions from industrialized countries must be reduced to lesser than $6 \%$ by 2012 [2]. Consequently, developing efficient technologies for $\mathrm{CO}_{2}$ emissions reduction, as well as moving to sustainable and abundant energy sources are urgent issues which stressed governments and nations.

The present technology for $\mathrm{CO}_{2}$ capture which is broadly adopted in the industry nowadays is the post-combustion system, whereby the flue gas separation takes place after the combustion process of fossil fuel. The benefits of this process include ease in retrofitting the existing power plants and flexibility of the process, whereby the power plant is still capable to operate even if there are malfunctions in the capturing system [3]. The most likely location for the capture plant is between the flue gas desulfurization unit and the stack. At this point, flue gases are at near atmospheric pressure and $\mathrm{CO}_{2}$ represents between $3 \%$ and $20 \%$ by volume (depending on the fuel used, and if dry or wet basis conditions are considered). Chemical absorption with amine-based or ammonia-based absorbent receives the greatest attention due to its high process efficiency, and thus, is widely performed by industrialists. Despite the good performance of absorption technology in capturing $\mathrm{CO}_{2}$ it is not yet widely implemented at commercial scale on coal or gas-fired power plants. Heavy consumption of amine-based 
solvent contributes towards equipment corrosion, and hence, requires special materials for equipment construction which can withstand corrosion of these chemicals [4]. In addition, a higher energy input is imposed during solvent regeneration process due to stronger chemical interaction between $\mathrm{CO}_{2}$ and basic amine solvent [5]. Solid sorbent based adsorption is proposed as an alternative to the current state of the art technology. The adsorption scheme is said to offer miscellaneous advantages including high adsorption capacity at ambient conditions, low regeneration cost, long-term stability, fast kinetics, evading moisture removal from flue gas, and ease of handling [6]. Moreover, adsorption aims to reduce the energy penalty of the capture process by eliminating the need of heating a vast amount of water (up to $70 \%$ by weight of the solvent). Adsorbents can be regenerated through a pressure swing or thermal swing process. The main requirements of $\mathrm{CO}_{2}$ adsorbents are: low cost, high resistance, sufficient adsorption capacity and selectivity under the operation conditions, and easy regeneration.

The second mature strategy to reduce $\mathrm{CO}_{2}$ emissions is to adopt renewable energy carriers which emissions are environmentally-friendly. Among many options, hydrogen is widely considered as an ideal energy carrier. It stores an extremely high gravimetrical energy density $(142 \mathrm{MJ} / \mathrm{kg}$ ) which is at least three times greater than the equivalent value for liquid hydrocarbons (47 MJ/kg). Besides, the only exhaust product in both combustion and fuel cell engines is water vapor. Among the many hurdles that the implementation of hydrogen economy faces, there is the storage for its transportation and onboard use. The classical $\mathrm{H}_{2}$ storage technologies show some important drawbacks such as low density and high pressure operations for compression, and boil-off excessive energy consumption for liquefaction[7]. An alternative solution is therefore hydrogen storage in solid materials. Here three principle storage mechanisms can be distinguished: i) chemisorption and absorption of hydrogen atoms in metals ii) formation of compounds with ionic character, like complex hydrides and iii) 
physisorption (or physical adsorption) of hydrogen molecules on porous materials. Adsorptive storage exhibits several advantages over chemical hydrogen storage as for example the complete reversibility and the fast kinetics. In addition a very small amount of energy $\left(<10 \mathrm{~kJ} \mathrm{~mol}^{-1}\right)$ is involved both in the adsorption and in the release of $\mathrm{H}_{2}$. In contrast to hydrogen stored in metal hydrides and complex hydrides, no extra heat management systems are therefore required for on-board applications.

In sum, storing or capturing gas by means of adsorption seems to be very advantageous, thanks to its thermodynamic properties, and it could involve low cost and sustainable materials such as activated carbons. These materials represent the oldest carbon class; they can be generated from any carbon-rich material through physical or chemical activations. Further details about the preparation of carbon adsorbents can be found elsewhere[8]. Not only the activated carbons are low cost adsorbents, they also possess good chemical and thermo-mechanical stability, and allow easy regeneration strategies. In addition, unlike crystallographic microporous adsorbents (i.e., zeolites and MOFs), activated carbons can be produced from a wide variety of biomass residues at industrial scale and their pores and surface properties can easily be tailored by rather simpler processing. Therefore, in the last few years a huge number of papers dealing with $\mathrm{CO}_{2}$ capture [9]-[12] as well as $\mathrm{H}_{2}$ storage [13]-[17]in biomass-derived activated carbons has been published.

This context represents the scope of the present study, in which activated carbon materials have been developed from olive stones. The latter is extracted from olive bagasse which is an abundant residue from the oleic industry in Tunisia: the mean annual olive oil production for the decade 2004-2014 was 180,000 ton and reached 299,000 ton in 2015 [18]. The raw granular was activated either directly, or after pyrolysis step, using potassium derivatives $\mathrm{KOH}$ and $\mathrm{K}_{2} \mathrm{CO}_{3}$. The carbon adsorbents were evaluated in terms of texture development and $\mathrm{H}_{2}$ and $\mathrm{CO}_{2}$ adsorption performance in a volumetric and a thermogravimetric apparatus. The 
adsorption of a binary mixture of $\mathrm{CO}_{2}$ and $\mathrm{N}_{2}$ with composition $10 \%$ of $\mathrm{CO}_{2}$ which can be considered representative of post-combustion capture conditions was assessed at $25^{\circ} \mathrm{C}$ and 50 ${ }^{\circ} \mathrm{C}$. The effect of porosity, and in particular microporosity, on gas uptake is discussed.

\section{Materials and methods}

\subsection{Preparation of activated carbons}

Two granular ACs were prepared through chemical activation; using $\mathrm{KOH}$ and $\mathrm{K}_{2} \mathrm{CO}_{3}$, of olive stones. Olive stones were freed from the olive bagasse which was collected from an olive oil factory located in the south of Tunisia. Firstly, the raw material was washed abundantly with hot distilled water to obtain grains of olive stones sized to about 1-3 mm.

$\mathrm{KOH}$ activation: prior to activation olive stones were pyrolysed at $300{ }^{\circ} \mathrm{C}$ for $1 \mathrm{~h}$ under nitrogen flow. Subsequently, the char was soaked in an aqueous solution of $\mathrm{KOH}$ at $85{ }^{\circ} \mathrm{C}$ without evaporation for $3 \mathrm{~h}$. The impregnation ratio (g KOH/g olive stones) was fixed at 7 . The resultant filtrate was carbonized under nitrogen flow rate of $300 \mathrm{~cm}^{3} \mathrm{~min}^{-1}$ and a heating rate of $10^{\circ} \mathrm{C} \min ^{-1}$ up to $350^{\circ} \mathrm{C}$ during $2 \mathrm{~h}$ and then up to $850^{\circ} \mathrm{C}$ for $3 \mathrm{~h}$. The activated sample was then washed several times with $\mathrm{HCl}$ solution $(0.1 \mathrm{M})$ to remove any inorganic salts and then washed with distilled water on a Soxhlet apparatus until neutral pH. Finally, the carbon was dried in an oven at $120^{\circ} \mathrm{C}$ and denoted as $\boldsymbol{A C} \_\boldsymbol{K O H}$.

$\mathrm{K}_{2} \mathrm{CO}_{3}$ activation: The precursor was impregnated in $\mathrm{K}_{2} \mathrm{CO}_{3}$ solution with an impregnation ratio $\left(\mathrm{gK}_{2} \mathrm{CO}_{3} / \mathrm{g}\right.$ precursor) of 1 and the mixture was kept under refluxed and boiling for $4 \mathrm{~h}$. Then, the filtered material was carbonized at $900^{\circ} \mathrm{C}$ for $2 \mathrm{~h}$ under $\mathrm{N}_{2}$ (flow rate $100 \mathrm{ml} \cdot \mathrm{min}^{-1}$; heating rate $\left.5^{\circ} \mathrm{C} \cdot \mathrm{min}^{-1}\right)$. The resultant $\mathrm{AC}$ was repeatedly washed with 0.1 $\mathrm{M} \mathrm{HCl}$ and hot distilled water and then dried. The carbon sample is labeled as $\boldsymbol{A C}_{-} \boldsymbol{K}_{2} \boldsymbol{C O}_{3}$. The carbonization step of the two samples was carried out on a tubular quartz tube kept inside a horizontal furnace.

\subsection{Textural characterization}


The morphology of the two prepared carbons was assessed by scanning electron microscopy (SEM) in a FEI Helios 600 Nanolab equipment.

The porous texture of the adsorbents was characterized by physical adsorption of $\mathrm{CO}_{2}$ at $0^{\circ} \mathrm{C}$ and up to $120 \mathrm{kPa}$ using a commercial adsorption apparatus (TriStar 3000 from Micromeritics). Prior to the measurements the samples were evacuated overnight at $100^{\circ} \mathrm{C}$. Actually, the narrow character of the micropores impeded the diffusion of $\mathrm{N}_{2}$ at $-196{ }^{\circ} \mathrm{C}$ in most cases. The use of $\mathrm{CO}_{2}$ as a probe molecule at $0{ }^{\circ} \mathrm{C}$ is recommended for the characterization of the narrow micropores to avoid underestimation of the pore volume by $\mathrm{N}_{2}$ adsorption at $-196{ }^{\circ} \mathrm{C}[19]$. The ultramicropore volume $\left(\mathrm{W}_{0}\right)$ and the micropore surface area $\left(S_{\text {mic }}\right)$ were determined by the Dubinin-Radushkevich (DR) equation [20] assuming a density of the adsorbed phase of $1.023 \mathrm{~cm}^{3} \mathrm{~g}^{-1}$, a cross sectional area of $0.187 \mathrm{~nm}^{2}$ and an affinity coefficient of 0.36 . The average micropore width $\left(\mathrm{L}_{0}\right)$ was calculated through the StoeckliBallerini equation[21].

\subsection{Hydrogen storage performance}

\subsubsection{Hydrogen adsorption isotherm measurements}

Determination of $\mathrm{H}_{2}$ storage at liquid nitrogen temperature $\left(-196^{\circ} \mathrm{C}\right)$ and up to 25 bar was carried out in a commercial Sieverts system (PCT Pro 2000 with microdoser, HyEnergy) at the Max Planck Institute for Intelligent Systems in Stuttgart. This apparatus measures automatically adsorption and desorption isotherms in a sample volume of $\approx 1.3 \mathrm{ml}$. Before each measurement, the sample (about $100 \mathrm{mg}$ ) was heated under vacuum at $250^{\circ} \mathrm{C}$ for $24 \mathrm{~h}$. The excess adsorption in wt.\% is calculated from:

$$
n_{e x}=100 \times \frac{\mathrm{n}_{\mathrm{exc}} \times \mathrm{M}}{\mathrm{n}_{\mathrm{exc}} \times \mathrm{M}+\mathrm{m}}
$$

where $\mathrm{M}$ denotes the molar mass of hydrogen $(\mathrm{M}=2.01588 \mathrm{~g}$ mol-1) and $\mathrm{m}$ denotes the sample mass. The measurement device automatically measures the free gas volume in the sample cell $\mathrm{V}_{\mathrm{He}}$ with helium gas at room temperature in the pressure range between 1 and 5 
bar. Therefore, the helium densities $\rho_{\mathrm{He}}$ were calculated from $\mathrm{V}_{\mathrm{He}}$, the volume of the empty cell $\mathrm{V}_{0}$ and the sample mass $\mathrm{m}$, by:

$$
\rho_{H e}=\frac{\mathrm{m}}{\mathrm{V}_{0}-\mathrm{V}_{\mathrm{He}}}
$$

\subsubsection{Isosteric heat of adsorption measurements}

In cryogenic hydrogen storage applications, the heat of adsorption is a very important characteristic and has to be identified because hydrogen uptake at the low pressure range is strongly governed by this value. The apparent isosteric enthalpy of adsorption of hydrogen into the carbon pores, $\Delta \mathrm{H}_{\mathrm{ads}}$, can be estimated for different surface coverage using Vant' Hoff's equation:

$$
\left(\frac{\partial(\ln \mathrm{P})}{\partial\left(\frac{1}{\mathrm{~T}}\right)}\right)_{\theta}=\frac{\Delta \mathrm{H}_{\mathrm{ads}}}{\mathrm{R}}
$$

where P: pressure in bar; $\mathrm{T}$ in $\mathrm{K}$; $\mathrm{R}$ : molar gas constant and $\theta$ is the surface coverage. For calculations we used adsorption isotherms at $-196^{\circ} \mathrm{C}$ (liquid nitrogen) and $-186^{\circ} \mathrm{C}$ (liquid argon) and up to 25 bar.

\section{4 $\mathrm{CO}_{2}$ sorption measurements under post-combustion conditions}

The adsorption behavior of the activated carbons in conditions representative of postcombustion capture (at $25^{\circ} \mathrm{C}$ and $50^{\circ} \mathrm{C}$ and low partial pressure of $\mathrm{CO}_{2}$ ) was evaluated at atmospheric pressure in a thermogravimetric analyzer.

After an initial conditioning step carried out in $100 \mathrm{~cm}^{3} \mathrm{~min}^{-1}$ of $\mathrm{N}_{2}$ at $100{ }^{\circ} \mathrm{C}$ for $1 \mathrm{~h}$, the samples were cooled down to the adsorption temperature in $\mathrm{N}_{2}$ flow. The mass of the samples increases during the cooling stage due to adsorption of $\mathrm{N}_{2}$. Once the temperature of the sample stabilizes, so does the mass of the sample (the sample reaches thermal and adsorption equilibrium with the surrounding atmosphere). Buoyancy and dragging effects were appropriately corrected by running blank experiments. Assuming that the adsorption capacity 
of $\mathrm{N}_{2}$ at $100{ }^{\circ} \mathrm{C}$ can be considered negligible, it is possible to estimate the adsorption capacity of pure $\mathrm{N}_{2}\left(\mathrm{q}_{\mathrm{N} 2}\right)$ at the adsorption temperature $\left(50^{\circ} \mathrm{C}\right)$ as follows:

$$
\mathrm{q}_{\mathrm{N}_{2}}(\mathrm{w} . \mathrm{t} \%)=\frac{\mathrm{m}_{50, \mathrm{~N}_{2}}-\mathrm{m}_{100, \mathrm{~N}_{2}}}{\mathrm{~m}_{100 \mathrm{~N}_{2}}} \times 100
$$

where $m_{100, N_{2}}$ is the mass of the sample measured at the end of the drying step at $100{ }^{\circ} \mathrm{C}$ in the $\mathrm{N}_{2}$ flow, and $m_{50, N_{2}}$ is the mass of sample at $50{ }^{\circ} \mathrm{C}$ at the end of the cooling step in the $\mathrm{N}_{2}$ flow. After $1 \mathrm{~h}$, the composition of the feed was switched from $100 \% \mathrm{~N}_{2}$ to a mixture consisting of $10 \% \mathrm{CO}_{2}$ and $90 \% \mathrm{~N}_{2}$ and the temperature was kept constant. As a consequence, the mass of the sample increased due to the adsorption of $\mathrm{CO}_{2}$ from the gas mixture. The total mass uptake is expressed as weight percentage taking as reference the mass of the sample at the end of the drying step (as mentioned before, the adsorption capacity of $\mathrm{N}_{2}$ at $100{ }^{\circ} \mathrm{C}$ is assumed to be negligible):

$$
\mathrm{q}_{\mathrm{N}_{2}+\mathrm{CO}_{2}}(\mathrm{w} . \mathrm{t} \%)=\frac{\mathrm{m}_{50,\left(\mathrm{~N}_{2}+\mathrm{CO}_{2}\right)}-\mathrm{m}_{100, \mathrm{~N}_{2}}}{\mathrm{~m}_{100 \mathrm{~N}_{2}}} \times 100
$$

where $\mathrm{q}_{\mathrm{N}_{2}+\mathrm{CO}_{2}}$ is the total mass uptake, which includes the amount of $\mathrm{CO}_{2}$ and $\mathrm{N}_{2}$ adsorbed and $\mathrm{m}_{50,\left(\mathrm{~N}_{2}+\mathrm{CO}_{2}\right)}$ is the mass of the sample under flow of the $10 \% \mathrm{CO}_{2}-90 \% \mathrm{~N}_{2}$ mixture at the end of the adsorption step at $50{ }^{\circ} \mathrm{C}$. Finally, the samples were regenerated by switching the composition of the gas back to $100 \% \mathrm{~N}_{2}$ at constant temperature. If mass transfer resistances are negligible, the equilibrium of adsorption will be attained immediately. However, this is rarely the case.

\section{Kinetic models}

For investigating kinetics of $\mathrm{CO}_{2}$ adsorption using $\mathrm{AC}-\mathrm{K}_{2} \mathrm{CO}_{3}$ and $\mathrm{AC}-\mathrm{KOH}$, two commonly kinetic models, namely pseudo-first order of Largergren and pseudo-second order were applied. The pseudo-first order model considers that the adsorption rate is proportional to the number of free adsorption sites: 


$$
\frac{d q}{d t}=\mathrm{K}\left(q_{e}-\mathrm{q}\right)
$$

where $\mathrm{k}$ is the apparent adsorption rate constant, $\mathrm{q}_{\mathrm{e}}$ represents the amount adsorbed at equilibrium, and q the amount adsorbed at a given time. By integrating Eq. (6) with the following boundary conditions: for $\mathrm{t}=0 \mathrm{q}=0$ and for $\mathrm{t}=1 \mathrm{q}=\mathrm{q}_{\mathrm{e}}$, we obtain the following expression for the uptake curve [22]:

$$
\mathrm{q}=q_{e}\left(1-e^{-\mathrm{k} t}\right)
$$

However, the pseudo-second order model allows a greater dependence on loading than the pseudo-first order model. This model is useful for describing solid diffusion rate controlled processes that are not properly described by the other model approximation.

$$
\frac{d q}{q t}=\mathrm{k}\left(q_{e}-\mathrm{q}\right)^{2}
$$

The corresponding integrated equation with the aforementioned boundary conditions is:

$$
\mathrm{q}=\frac{q_{e}{ }^{2} \mathrm{k} t}{1+q_{e} \mathrm{k} t}
$$

The apparent rate constants of the lumped models were fitted to minimize the sum of square residuals between the experimental mass uptake and that given by the model:

$$
\text { Goodness of fit }=\sqrt{\frac{\sum_{i=1}^{N}\left(q_{\text {exp }}-q_{\text {model }}\right)_{i}{ }^{2}}{N-1}}
$$

where $\mathrm{N}$ represents the number of experimental data points fitted for each sample (from the beginning of the mass uptake up to the equilibrium $\left.\left(\mathrm{q} / \mathrm{q}_{\mathrm{e}}=1\right)\right)$.

\section{Results and discussion}

\subsection{Characterization of the activated carbons}

SEM micrographs of two carbon materials are shown in fig. 1. The two samples exhibit a sponge-like structure with a "fluffy" appearance. The strongly nucleophilic hydroxyl ion has caused the fragmentation and partial dissolution of the lignocellulosic framework which has led to the swelling of internal channels [23]. However, the comparison of the two images 
demonstrates that the sponge like structure is localized at the external surface of $\mathrm{AC}_{-} \mathrm{K}_{2} \mathrm{CO}_{3}$ unlike that in the case of $\mathrm{KOH}$-activated carbon. This could be attributed to incomplete reaction between the olive stones and $\mathrm{K}_{2} \mathrm{CO}_{3}$. Partial evaporation of $\mathrm{K}_{2} \mathrm{CO}_{3}$ occurs when the carbonization is performed at $900{ }^{\circ} \mathrm{C}$, which is above the melting point of $\mathrm{K}_{2} \mathrm{CO}_{3}, 891{ }^{\circ} \mathrm{C}$.

Table 1 summarizes the textural properties in the microporosity domain of the activated carbons obtained in this study. One can note that the two samples have high internally developed surface areas with narrow mean pore size $\left(\mathrm{L}_{0}<0.7 \mathrm{~nm}\right)$. However, the $\mathrm{AC}_{-} \mathrm{K}_{2} \mathrm{CO}_{3}$ sample resembles a biochar because of its relatively low micropore volume and very narrow micropore size. This is consistent with the SEM observations. In contrast, the AC_KOH sample has more opened porosity thus a higher micropore surface area and a higher micropore volume was shown by this carbon. This is probably related to the carbon synthesis procedures as well as to the used impregnation ratio. Actually, in the $\mathrm{AC}_{-} \mathrm{K}_{2} \mathrm{CO}_{3}$ sample the impregnated precursor was the olive stones, while for the $\mathrm{AC} \_\mathrm{KOH}$ sample it was the biochar, which already has a rudimentary developed porosity. On the other hand, Marsh et al. [24] and Otowa et al. [25] confirmed that the potassium metals liberated at the reaction temperature may intercalate and expand the carbon layers. Hence, higher impregnation ratio produces an enlargement on the carbon's porosity.

Table 1. Textural characteristics of the microporosity of the prepared activated carbons

\begin{tabular}{ccccc}
\hline Carbons & $\begin{array}{c}\mathbf{S}_{\text {mic }} \\
\left(\mathbf{m}^{2} \cdot \mathbf{g}^{-1}\right)\end{array}$ & $\begin{array}{c}\mathbf{L}_{\mathbf{0}} \\
(\mathbf{n m})\end{array}$ & $\mathbf{W}_{\mathbf{0}}\left(\mathbf{c m}^{3} \cdot \mathbf{g}^{-1}\right)$ & $\rho_{\mathrm{He}}\left(\mathbf{g ~ c m}^{-3}\right)$ \\
\hline $\mathrm{AC}_{-} \mathrm{K}_{2} \mathrm{CO}_{3}$ & 989 & 0.53 & 0.26 & 1.60 \\
$\mathrm{AC} \_\mathrm{KOH}$ & 1173 & 0.69 & 0.41 & 1.75 \\
\hline
\end{tabular}


Table 2. Recent physically-activated carbon production for $\mathrm{CO}_{2}$ capture (year 2009-2015)

\begin{tabular}{|c|c|c|c|c|}
\hline Precursors & Details of preparation & $\begin{array}{l}\text { Max surface } \\
\text { area }\left(\mathrm{m}^{2} / \mathrm{g}\right)\end{array}$ & $\begin{array}{c}\mathrm{W}_{0} \\
\left(\mathrm{~cm}^{3} / \mathbf{g}\right)\end{array}$ & Reference \\
\hline Olives stones & $\begin{array}{l}\text { Two step activation } \\
-\quad \text { Carbonization at } 600^{\circ} \mathrm{C} \text { in } \mathrm{N}_{2} \text { flow } \\
\text { - Activation with } 10 \mathrm{~cm}^{3} \mathrm{~mm}^{-1} \text { of } \mathrm{CO}_{2} \text { at } \\
\\
800^{\circ} \mathrm{C} \text { and up to } 50 \% \text { of burn off degree }\end{array}$ & $\mathrm{S}_{\mathrm{BET}}=1079$ & 0.24 & [11] \\
\hline Almond shell & $\begin{array}{l}\text { Two step activation } \\
-\quad \text { Carbonization at } 600^{\circ} \mathrm{C}_{\text {in }} \mathrm{N}_{2} \text { flow } \\
\text { - Activation with } 10 \mathrm{~cm}^{3} \mathrm{~mm}^{-1} \text { of } \mathrm{CO}_{2} \text { at } \\
\quad 700^{\circ} \mathrm{C} \text { and up to } 50 \% \text { of burn off-degree }\end{array}$ & $\mathrm{S}_{\mathrm{BET}}=1090$ & 0.12 & [10] \\
\hline Coffee residue & $\begin{array}{l}\text { Two step activation } \\
-\quad \text { Carbonization at } 600^{\circ} \mathrm{C} \text { in } \mathrm{N}_{2} \text { flow } \\
\text { - Activation with } 10 \mathrm{~cm}^{3} \mathrm{~mm}^{-1} \text { of } \mathrm{CO}_{2} \text { at } \\
\quad 700^{\circ} \mathrm{C} \text {. }\end{array}$ & $\mathrm{S}_{\mathrm{BET}}=593$ & 0.25 & [26] \\
\hline $\begin{array}{l}\text { Macademia } \\
\text { nut shell }\end{array}$ & $\begin{array}{l}\text { Two step activation } \\
-\quad \text { Carbonization at } 600^{\circ} \mathrm{C} \text { in } \mathrm{N}_{2} \text { flow } \\
\text { - Activation with } 500 \mathrm{~cm}^{3} \mathrm{~mm}^{-1} \text { of } \mathrm{CO}_{2} \text { at } \\
\quad 900^{\circ} \mathrm{C} \text {. }\end{array}$ & $\mathrm{S}_{\mathrm{BET}}=573$ & - & [27] \\
\hline Cotton stalk & $\begin{array}{l}\text { Two step activation } \\
\text { - Carbonization at } 600^{\circ} \mathrm{C} \text { in } \mathrm{N}_{2} \text { flow } \\
\text { - Activation on } \mathrm{CO}_{2} \text { flow at } 800^{\circ} \mathrm{C} \text {. }\end{array}$ & $\mathrm{S}_{\mathrm{BET}}=610$ & - & [28] \\
\hline Coconut shell & $\begin{array}{l}\text { Single step activation with } 150 \mathrm{~cm}^{3} \mathrm{~mm}^{-1} \mathrm{CO}_{2} \text { flow } \\
\text { at } 900^{\circ} \mathrm{C}\end{array}$ & $\mathrm{S}_{\mathrm{BET}}=371$ & - & [29] \\
\hline Olive stones & $\begin{array}{l}\text { Single step activation with } 100 \mathrm{~cm}^{3} \mathrm{~mm}^{-1} \text { of } \mathrm{O}_{2} \\
\text { flow }(3 \%) \text { at } 650^{\circ} \mathrm{C}\end{array}$ & $\mathrm{S}_{\mathrm{mic}}=697$ & 0.27 & [30] \\
\hline Almond shell & $\begin{array}{l}\text { Single step activation with } 100 \mathrm{~cm}^{3} \mathrm{~mm}^{-1} \text { of } \mathrm{O}_{2} \\
\text { flow }(3 \%) \text { at } 650^{\circ} \mathrm{C}\end{array}$ & $\mathrm{S}_{\mathrm{mic}}=557$ & 0.21 & [30] \\
\hline Coffee residue & Single step CO2 activation & $\mathrm{S}_{\mathrm{BET}}=522$ & 0.23 & [31] \\
\hline
\end{tabular}

Referring to the recent work published on physically-activated carbon production for $\mathrm{CO}_{2}$ capture, summarized in Table 2, it is shown that $\mathrm{KOH}$ activation of biomass (Table 1) is more efficient in the creation of microporosity. Besides, $\mathrm{KOH}$ as activating agent imposes lower energy requirement as compared to the two step physical activation, aside from lower environmental impact when compared to other chemical agents such as $\mathrm{ZnCl}_{2}$ and $\mathrm{H}_{3} \mathrm{PO}_{4}$. As mentioned above, during $\mathrm{KOH}$ activation intercalation of metallic potassium $(\mathrm{K})$ into the carbon structure would widen the space between the carbon layers. Therefore, the pore volume of the synthesized activated carbon is enhanced. Upon the washing process, the metallic potassium would be detached from the carbon matrix and leave a free interlayer space that contributes to porosity[32]. $\mathrm{KOH}$ bBeing a strong base, Sudaryanto et al. [33] 
proposed that it can act as catalyst to promote the oxidation process, in which the carbons are oxidized, and to widen the pore width. However, Wang et al.[34] suggested that the development of greater microporosity and surface area under $\mathrm{KOH}$ activation may be attributed to the collaborative effects of chemical activation that entails redox reaction of $\mathrm{KOH}$ to carbonate, in-situ physical activation that involves carbon gasification with $\mathrm{CO}_{2}$, and expansion of carbon lattices due to the intercalation of the potassium compounds. Hence, the following reactions may take place during the activation processes at high temperature:

$2 \mathrm{KOH} \longrightarrow \mathrm{K}_{2} \mathrm{O}+\mathrm{H}_{2} \mathrm{O}$ (dehydration)

$\mathrm{C}+\mathrm{H}_{2} \mathrm{O} \longrightarrow \mathrm{H}_{2}+\mathrm{CO} \quad$ (water-gas reaction)

$\mathrm{CO}+\mathrm{H}_{2} \mathrm{O} \longrightarrow \mathrm{H}_{2}+\mathrm{CO}_{2}$ (water-gas shift reaction)

$\mathrm{K}_{2} \mathrm{O}+\mathrm{CO}_{2} \longrightarrow \mathrm{K}_{2} \mathrm{CO}_{3}$ (carbonate formation)

$\mathrm{K}_{2} \mathrm{O}+\mathrm{H}_{2} \longrightarrow 2 \mathrm{~K}+\mathrm{H}_{2} \mathrm{O}$ (reduction by hydrogen)

$\mathrm{K}_{2} \mathrm{O}+\mathrm{C} \longrightarrow 2 \mathrm{~K}+\mathrm{CO}$ (reduction by carbon)

\subsection{Cryogenic hydrogen storage}

The excess $\mathrm{H}_{2}$ adsorption isotherms of the ACs up to 25 bar are displayed in Fig. 2(a). At $196^{\circ} \mathrm{C}$ all investigated carbon materials show a type I adsorption isotherm with an initial steep increase of the hydrogen uptake at low pressures and an almost horizontal plateau at higher pressures. This type of isotherm is characteristic for monolayer adsorption on microporous solids [35]. No multilayers of hydrogen are formed at $-196^{\circ} \mathrm{C}$, because the interaction strength between single layers is too weak at temperature higher than the critical temperature of $\mathrm{H}_{2}(-$ $\left.240^{\circ} \mathrm{C}\right)$.

At very low pressure the $\mathrm{K}_{2} \mathrm{CO}_{3}$-activated carbon exhibits higher $\mathrm{H}_{2}$ uptake compared to the other carbon (see fig.2(b)), revealing stronger binding energy between hydrogen molecules and this carbon. The only exceptional feature of this sample is its ultramicroporous character (it has the lowest median pore size $0.53 \mathrm{~nm}$ ). This clearly points out that the pore 
size is also a key factor that governs cryogenic $\mathrm{H}_{2}$ adsorption at certain pressure conditions. In the narrow pores, the overlap of van der Waals potentials due to the atoms of adjacent walls favors stronger physisorption. Nevertheless, as this range of pore is saturated under a pressure of $c a .100$ Torr, the sample ceases to show high hydrogen uptake capacity above this pressure range. This result is consistent with the micropore filling model. This means no contribution from capillary condensation could be occurred at these operation conditions

At 25 bar, the cryogenic $\mathrm{H}_{2}$ uptake of $\mathrm{AC} \_\mathrm{KOH}$ reaches about 3 wt.\%, which is an interesting result. Table 3 represents a collection of some publications which studied the $\mathrm{H}_{2}$ storage capacity of synthetic nanoporous materials. The overview of the Table 3 reveals that the two prepared carbons have outperformed a large number of nanoporous materials such as Zeolites, polymers and MOFs. For instance, the saturation of zeolites was reached at pressures lower than 15 bar with capacities lower than our achievements. Moreover, our ACs can store over $25 \%$ more $\mathrm{H}_{2}$ than advanced MOFs, over $29 \%$ more than nanoporous polymers and over $30 \%$ more than the Prussian blue. Since polymers and MOFs have specific surface area comparable to or higher than that of ACs, the observed uptake variations could be explained by the presence of a narrow distribution of small pores in the prepared ACs.

Table 3. Comparison of the $\mathrm{H}_{2}$ adsorption at $-196^{\circ} \mathrm{C}$ for non-carbonaceous adsorbents

\begin{tabular}{|c|c|c|c|c|c|}
\hline \multicolumn{7}{|c|}{ extensively studied for $\mathrm{H}_{2}$ storage } \\
\hline $\begin{array}{c}\text { Materials } \\
\mathbf{S}_{\mathbf{B E T}}\end{array}$ & $\mathbf{T}(\mathbf{K})$ & $\mathbf{P}(\mathbf{b a r})$ & $\begin{array}{c}\mathbf{H}_{\mathbf{2}} \\
\mathbf{u p t a k e s} \\
(\mathbf{w t} \%)\end{array}$ & References \\
\hline $\begin{array}{c}\text { Zeolites } \\
(\mathrm{NaA})\end{array}$ & 725 & $-196^{\circ} \mathrm{C}$ & 15 & 1.54 & {$[36]$} \\
\hline $\begin{array}{c}\text { Zeolites } \\
(\mathrm{CaX})\end{array}$ & 669 & $-196^{\circ} \mathrm{C}$ & 15 & 2.19 & {$[37]$} \\
\hline $\begin{array}{c}\text { Prussian Blue } \\
\end{array}$ & 870 & $-196^{\circ} \mathrm{C}$ & 1 & 1.4 & {$[38]$} \\
\hline
\end{tabular}




\begin{tabular}{|c|c|c|c|c|c|}
\hline $\begin{array}{c}\text { Polymers of intrinsic } \\
\text { microporosity (PIM) }\end{array}$ & 830 & $-196^{\circ} \mathrm{C}$ & 1 & 1.43 & {$[39]$} \\
\hline $\begin{array}{c}\text { Hypercrosslinked } \\
\text { polystyrene gel }\end{array}$ & 1930 & $-196^{\circ} \mathrm{C}$ & 1.2 & 1.55 & {$[40]$} \\
\hline Zr-MOF & 1367 & $-196^{\circ} \mathrm{C}$ & 1 & 1.5 & {$[41]$} \\
\hline MOF (Mil-101) & 1715 & $-196^{\circ} \mathrm{C}$ & 1 & 1.65 & {$[42]$} \\
\hline Zr-fumarate MOF & 849 & $-196^{\circ} \mathrm{C}$ & 1 & 1.38 & {$[43]$} \\
\hline Fly ash derived Zeolites X & 404 & $-196^{\circ} \mathrm{C}$ & 1 & 0.7 & {$[44]$} \\
\hline AC_KOH & S & $-196^{\circ} \mathrm{C}$ & 1 & 2 & This study \\
& & $-196^{\circ} \mathrm{C}$ & 25 & 2.96 & \\
\hline AC_K $\mathrm{K}_{2} \mathrm{CO}_{3}$ & Smic=989 & $-196^{\circ} \mathrm{C}-$ & 1 & 1.40 & This study \\
\hline
\end{tabular}

For many years, the investigators have stressed the effect of the surface area and the micropore volume on the cryogenic hydrogen uptake [45]-[47]. Therefore, this study is a real confirmation that surface area is not the only parameter that needs to be regarded. In addition, this study justifies previous works which proved the existence of an optimum pore size for $\mathrm{H}_{2}$ adsorption [48]-[51]. These optimum values can hold two layers of adsorbed hydrogen into slit pores. From application point of view it is possible to store hydrogen at $-196^{\circ} \mathrm{C}$ for stationary and some non-stationary applications. That said, nitrogen used as a coolant for the AC tanks is clean, safe, cheap, and its technology well established and commonly used[52]. Zini et al. [53], [54] have already implemented and validated model that describe solar and wind-hydrogen hybrid systems with activated carbon storage.

In fig.3 the isosteric enthalpy of adsorption is shown in dependence of the surface coverage, which is the hydrogen uptake normalized to the uptake at 25 bar and $-196^{\circ} \mathrm{C}$. The ultramicroporous carbon $\mathrm{AC}_{-} \mathrm{K}_{2} \mathrm{CO}_{3}$ has the highest enthalpy of adsorption with average 5.27 $\mathrm{kJ} . \mathrm{mol}^{-1}$ up to a surface coverage of $70 \%$. Subsequently is the carbon AC_KOH with average 
$4.94 \mathrm{~kJ} \cdot \mathrm{mol}^{-1}$. Both enthalpies can be regarded as constant within the experimental uncertainty which is approximately $0.5 \mathrm{~kJ} \cdot \mathrm{mol}^{-1}$. It seems that the $\mathrm{H}_{2}$ adsorption enthalpy correlates well with the pore diameter of the tested carbon; the smaller the pore is the higher is the binding energy to hydrogen molecules.

\section{3 $\mathrm{CO}_{2}$ capture performance}

\subsection{1 $\mathrm{CO}_{2}$ adsorption at $\mathrm{O}^{\circ} \mathrm{C}$}

Fig. 4 shows $\mathrm{CO}_{2}$ adsorption isotherms of the two prepared activated carbons at $0{ }^{\circ} \mathrm{C}$ up to atmospheric pressure by the volumetric method. It is important to note that the saturation pressure at $0{ }^{\circ} \mathrm{C}$ is approximately 35 bar, so the measured range up to 1 bar corresponds to relative pressures $\left(\mathrm{P} / \mathrm{P}^{0}\right)$ of up to 0.03 . In general, the $\mathrm{CO}_{2}$ isotherms can be classified as Type I, i.e., they are representative of strong adsorbate-adsorbent interactions. However, the $\mathrm{CO}_{2}$ adsoption isotherm of $\mathrm{AC} \_\mathrm{KOH}$ tends to be more rectilinear as compared to that of the AC_ $\mathrm{K}_{2} \mathrm{CO}_{3}$ activated carbon. This is due to the widening of the micropores s after the two step-KOH activation of olive stones, as shown in Table 1 . However, at very low pressures the AC_ $\mathrm{K}_{2} \mathrm{CO}_{3}$ showed the highest $\mathrm{CO}_{2}$ uptake (see fig.4(b)). Presser et al. [55] studied the effect of carbon pore size on the $\mathrm{CO}_{2}$ uptake of carbide derived carbon. Their findings reported that at 0.1 bar pores smaller or equal to $0.5 \mathrm{~nm}$ contribute the most to the $\mathrm{CO}_{2}$ uptake. While, at 1 bar pores smaller than $0.8 \mathrm{~nm}$ are preferred. This study clearly confirms their findings, as in sample $\mathrm{AC} \_\mathrm{K}_{2} \mathrm{CO}_{3}$ the creation of microporosity narrower than $0.5 \mathrm{~nm}$ is maximum.

Interestingly, the activated carbon $\mathrm{AC} \_\mathrm{KOH}$ exhibits a high $\mathrm{CO}_{2}$ capture capacity of 5.6 mmol $\mathrm{g}^{-1}$ at $0^{\circ} \mathrm{C}$ and $1 \mathrm{bar}$. This value may not be the highest published in the literature but it is within the greatest for biomass-derived carbons.

Table 4. $\mathrm{CO}_{2}$ uptake at 1 bar and $0^{\circ} \mathrm{C}$ of various carbon materials in comparison with

$$
\mathrm{AC} \_\mathrm{KOH} \text { and } \mathrm{AC} \_\mathrm{K}_{2} \mathrm{CO}_{3}
$$

\begin{tabular}{|c|c|c|c|c|c|}
\hline Materials & Precursor & Activation & S BET $_{\text {Bet }}$ & $\mathrm{CO}_{2}$ uptake & Reference \\
\hline
\end{tabular}




\begin{tabular}{|c|c|c|c|c|c|}
\hline & & & $\left(m^{2} \cdot g^{-1}\right)$ & $\left(\mathrm{mmol} \mathrm{g}^{-1}\right)$ & \\
\hline Purified SWNTs & - & - & 1587 & 5.1 & {$[56]$} \\
\hline Activated carbon fibers & - & - & - & 3.21 & [57] \\
\hline Activated carbon fibers & - & - & 1247 & 3.19 & {$[58]$} \\
\hline Biochar & Coffee residue & $\mathrm{CO}_{2}$ & 522 & 3.7 & {$[31]$} \\
\hline Biochar & Olive stones & $\mathrm{O}_{2}$ & - & 3.2 & {$[30]$} \\
\hline Activated carbon & Palm stones & $\mathrm{H}_{3} \mathrm{PO}_{4}$ & 1320 & 3.1 & [59] \\
\hline Activated carbon & Palm wastes & $\mathrm{CaCl}_{2}$ & 1445 & 5.7 & {$[60]$} \\
\hline Activated carbon & Coconut shells & $\mathrm{CO}_{2}$ & 1327 & 5.6 & [61] \\
\hline Activated carbon & Algae & $\mathrm{KOH}$ & 418 & 2.4 & [62] \\
\hline Activated carbon & Sawdust & $\mathrm{KOH}$ & 1250 & 6.1 & {$[63]$} \\
\hline Activated carbon & Celtuce leaves & $\mathrm{KOH}$ & 3404 & 6.0 & [64] \\
\hline Activated carbon & $\begin{array}{l}\text { Empty fruit bunch } \\
\text { (EFB) of oil palm trees }\end{array}$ & $\mathrm{KOH}$ & 2510 & 5.2 & {$[65]$} \\
\hline Activated carbon & Fungi & $\mathrm{KOH}$ & 1479 & 5.5 & [34] \\
\hline Activated carbon & Olive stones & $\mathrm{KOH}$ & - & 5.6 & This study \\
\hline Activated carbon & Olive stones & $\mathrm{K}_{2} \mathrm{CO}_{3}$ & - & 3.8 & This study \\
\hline
\end{tabular}

Table 4 shows a comparison of $\mathrm{CO}_{2}$ adsorption capacities at 1 bar for the ACs developed in this work, with those reported in the literature for carbon derived materials from different precursors. One can note that the $\mathrm{CO}_{2}$ adsorption capacities achieved in this study are much higher than those reported for nanostructured carbon materials. Besides, these materials are not yet produced in an industrial continuous process and a mass production of the carbon nanotubes and nanofibers is not yet possible. It is clearly seen that the nature of the precursor as well as the activation process are determining parameters for the $\mathrm{CO}_{2}$ adsorption behavior of the ACs. However, there is no dependency between the created surface area and the $\mathrm{CO}_{2}$ uptake of carbons as it was reported for hydrogen storage. Hence, only tailoring the pore system is crucial for the design of effective $\mathrm{CO}_{2}$ adsorbents. 


\subsection{2 $\mathrm{CO}_{2}$ adsorption under the real post-combustion operation conditions: high temperature}

and low $\mathrm{CO}_{2}$ partial pressure

The actual temperature of flue gas streams in post-combustion capture technology, considering the presence of a desulfurization unit, is often around $50^{\circ} \mathrm{C}$. Therefore, an extensive work which focused on $\mathrm{CO}_{2}$ at $0^{\circ} \mathrm{C}$ does not reflect the real condition of flue gas stream in power plant. In addition, applicability of the activated carbons in capturing $\mathrm{CO}_{2}$ at higher temperatures can reduce the operational cost of cooling the flue gas to lower temperature, and makes the process more economically attractive [66]. Moreover, in postcombustion technology the flue gas is usually simplified as $\mathrm{CO}_{2} / \mathrm{N}_{2}$ binary mixture due to the lower presence of other components (excluding water vapor). Consequently, the challenge in post-combustion $\mathrm{CO}_{2}$ adsorption is related to higher $\mathrm{CO}_{2} / \mathrm{N}_{2}$ adsorption selectivity. Therefore, in this section the two prepared olive stone-derived activated carbons will be exposed to a10\% $\mathrm{CO}_{2}$ flow at 25 and $50^{\circ} \mathrm{C}$ and atmospheric pressure. To the best of our knowledge, the only previous work dealing with this very specific conditions was the investigation reported by Plaza et al. [67], which will serve as reference in the discussion.

In Fig.5 the adsorption capacity of the samples at equilibrium, both in $100 \% \mathrm{~N}_{2}$ and in a mixture of $10 \% \mathrm{CO}_{2}$ (balance $\mathrm{N}_{2}$ ), are compared on a mass basis. At both temperatures, 25 and $50^{\circ} \mathrm{C}, \mathrm{AC} \_\mathrm{K}_{2} \mathrm{CO}_{3}$ shows the lowest $\mathrm{N}_{2}$ uptake, affirming the ultramicroporous character of this sample. However, under the post-combustion mixture, the mass uptakes of the two carbons are quite similar at $25^{\circ} \mathrm{C}$, while at $50^{\circ} \mathrm{C}$ the greatest mass uptake is attained by AC_ $\mathrm{K}_{2} \mathrm{CO}_{3}$ (fig.5(b)); it has lower micropore volume but significantly narrower micropore size (see Table 1). Hence, narrow micropores seem the key factor which governs the adsorption $\mathrm{CO}_{2}$ in post combustion condition (low partial pressure of $\mathrm{CO}_{2}$ ) [68], [69]. At increased temperature, $\mathrm{CO}_{2}$ molecules have higher mobility and there is instability of the adsorbed $\mathrm{CO}_{2}$ molecules. This is attributed to the high surface adsorption energy and 
molecular diffusion [70]. Accordingly, desorption of $\mathrm{CO}_{2}$ adsorbed will take place. In this study it seems that $\mathrm{CO}_{2}$ desorption was impeded by the narrower pore size of $A \mathrm{~A}_{-} \mathrm{K}_{2} \mathrm{CO}_{3}$ and so its mass uptake from the post-combustion mixture was higher than that of $\mathrm{AC} \_\mathrm{KOH}$. The reduction on $\mathrm{CO}_{2}$ adsorption by rising temperature proves that $\mathrm{CO}_{2}$ adsorption on activated carbons is an exothermic and physisorption based process that is favored at low temperatures. It is worth mentioning that the values reported in this work are higher than those achieved by Plaza et al. [67]. These investigators have prepared kind of pine sawdust-derived activated carbon pellets. The activation was either single step $\mathrm{CO}_{2}$ activation, or air oxidation followed by $\mathrm{CO}_{2}$ activation at $800^{\circ} \mathrm{C}$ for $2 \mathrm{~h}$. The pelletized samples were nominated as $\mathrm{IH} 2, \mathrm{IH} 3$ and IH4. The highest uptake from the post-combustion mixture at $50{ }^{\circ} \mathrm{C}$ was lower than $2.2 \mathrm{wt} \%$, attained by IH3.

Fig.6(a) and fig.7(a) show the results of the full adsorption experiments for the two carbons in terms of total mass uptake vs. time at 25 and $50{ }^{\circ} \mathrm{C}$, respectively. Samples are regenerated by simple switching the feed gas back to $100 \% \mathrm{~N}_{2}$ at constant temperature. The two samples present fast adsorption-desorption kinetics, which is crucial for the use of adsorbents in a post-combustion $\mathrm{CO}_{2}$ capture process. To evaluate the kinetics of adsorption, the dynamic mass uptake of the samples from the gas mixture was represented taking as a reference the mass of sample at the end of the conditioning step in $\mathrm{N}_{2}$ (see Fig. 6(b) and Fig.7(b)). This incremental mass uptake corresponds to the adsorption of $\mathrm{CO}_{2}$ from the mixture. However, the amount of $\mathrm{CO}_{2}$ adsorbed at equilibrium is expected to be somewhat higher than this incremental uptake, due to the displacement of part of the $\mathrm{N}_{2}$ initially adsorbed (the partial pressure of $\mathrm{N}_{2}$ decreases, and $\mathrm{CO}_{2}$ is expected to be preferentially adsorbed over $\mathrm{N}_{2}$ due to its higher quadrupole moment). The pseudo-first order model suitably describes the mass uptake of the activated carbons at 25 and $50^{\circ} \mathrm{C}$. The apparent rate constants that led to the best-fit of the experimental uptake curves are shown in Table 5. The apparent rate constants of 
AC_ $\mathrm{K}_{2} \mathrm{CO}_{3}$ are slightly lower than those of $\mathrm{AC} \_\mathrm{KOH}$. This is probably due to a greater diffusion resistance in the narrower porosity of $\mathrm{AC}_{-} \mathrm{K}_{2} \mathrm{CO}_{3}$.

At both temperatures, $\mathrm{AC}_{-} \mathrm{K}_{2} \mathrm{CO}_{3}$ shows the highest $\mathrm{CO}_{2}$ uptake. This result clearly highlights the effect of the carbon pore size on $\mathrm{CO}_{2}$ adsorption under post-combustion conditions. Even though AC_KOH has more developed microporosity it could not outperform the other sample. On the other hand, our results significantly improve the achievements of Plaza et al. [67].

Table 5. Apparent rate constant for the adsorption of $\mathrm{CO}_{2}$ on $\mathrm{AC} \_\mathrm{KOH}$ and $\mathrm{AC}_{-} \mathrm{K}_{2} \mathrm{CO}_{3}$

\begin{tabular}{|c|c|c|c|c|c|}
\hline \multirow{2}{*}{$\begin{array}{l}\text { Kinetic } \\
\text { models }\end{array}$} & \multirow[t]{2}{*}{ Parameter } & \multicolumn{2}{|c|}{$25^{\circ} \mathrm{C}$} & \multicolumn{2}{|c|}{$50^{\circ} \mathrm{C}$} \\
\hline & & AC_K $\mathrm{K}_{2} \mathrm{CO}_{3}$ & AC_KOH & AC_K $\mathrm{K}_{2} \mathrm{CO}_{3}$ & AC_KOH \\
\hline \multirow{3}{*}{$\begin{array}{c}\text { Pseudo-first- } \\
\text { order } \\
\text { LDF }\end{array}$} & $\mathrm{k}\left(\mathrm{s}^{-1}\right)$ & 0.538 & 0.807 & 0.705 & 1.012 \\
\hline & $\mathrm{q}_{\mathrm{e}}(\mathrm{wt} . \%)$ & 2.832 & 2.621 & 1.669 & 1.416 \\
\hline & $\mathrm{R}^{2}$ & 0.990 & 0.970 & 0.977 & 0.946 \\
\hline \multirow{3}{*}{$\begin{array}{c}\text { Pseudo- } \\
\text { second-order } \\
\text { QDF }\end{array}$} & $\mathrm{k}\left(\mathrm{s}^{-1}\right)$ & 0.346 & 0.594 & 0.804 & 1.424 \\
\hline & $\mathrm{q}_{\mathrm{e}}(\mathrm{wt} . \%)$ & 2.946 & 2.696 & 1.723 & 1.449 \\
\hline & $\mathrm{R}^{2}$ & 0.923 & 0.863 & 0.879 & 0.813 \\
\hline
\end{tabular}

\section{Conclusions}

This study compares the effect of $\mathrm{KOH}$ and $\mathrm{K}_{2} \mathrm{CO}_{3}$ activation on the hydrogen uptake and $\mathrm{CO}_{2}$ capture of activated carbons derived from olive pomace. $\mathrm{KOH}$ activation of the biochar leads to more opened porosity and higher surface area as compared to $\mathrm{K}_{2} \mathrm{CO}_{3}$ activation of the raw precursor. In general, potassium derivatives activation could be seen as an efficient technique to tune carbon's porosity.. Cryogenic hydrogen adsorption seems to follow the micropore filling model. The narrow pores saturate before the wider ones. Therefore, AC_KOH shows the highest $\mathrm{H}_{2}$ storage capacity ( $\left.\sim 3 w t \%\right)$. It was shown that at pressures higher than 1 bar, $\mathrm{H}_{2}$ adsorbents must have heterogeneous pore size distribution and high surface area to facilitate $\mathrm{H}_{2}$ accessibility. Similar behavior was shown by pure $\mathrm{CO}_{2}$ at $0^{\circ} \mathrm{C}$, thus sample $\mathrm{AC}-\mathrm{KOH}$ has shown outperformance with a capacity of $5.6 \mathrm{mmol} \mathrm{g}^{-1}$ at $1 \mathrm{bar}$. The post-combustion $\mathrm{CO}_{2}$ capture conditions were defined by low $\mathrm{CO}_{2}$ partial pressure 
$\left(\sim 10 \%, \mathrm{~N}_{2}\right.$ balance) and temperature of $50^{\circ} \mathrm{C}$. The thermogravimetric experiments clearly proved that ultramicropores $\left(\mathrm{L}_{0} \leq 0.5 \mathrm{~nm}\right)$ are of utmost importance to ensure high $\mathrm{CO}_{2}$ uptakes. Hence, $\mathrm{AC}_{-} \mathrm{K}_{2} \mathrm{CO}_{3}$ exhibited an exceptional capacity of about $1.67 \mathrm{wt} \%$ at $50^{\circ} \mathrm{C}$. Finally, one can conclude that $\mathrm{H}_{2}$ and $\mathrm{CO}_{2}$ adsorbent design should pass inevitably through pore structure tailoring.

\section{References}

[1] D. Y. C. Leung, G. Caramanna, and M. M. Maroto-Valer, "An overview of current status of carbon dioxide capture and storage technologies," Renew. Sustain. Energy Rev., vol. 39, pp. 426-443, Nov. 2014.

[2] "KyotoProtocol - Toward Climate Stability." [Online]. Available: http://www.kyotoprotocol.com/. [Accessed: 09-Nov-2016].

[3] T. Kuramochi, A. Ramírez, W. Turkenburg, and A. Faaij, "Comparative assessment of CO2 capture technologies for carbon-intensive industrial processes," Prog. Energy Combust. Sci., vol. 38, no. 1, pp. 87-112, Feb. 2012.

[4] P. N. Sutar, A. Jha, P. D. Vaidya, and E. Y. Kenig, "Secondary amines for CO2 capture: A kinetic investigation using N-ethylmonoethanolamine," Chem. Eng. J., vol. 207-208, pp. 718-724, Oct. 2012.

[5] M. Hasib-ur-Rahman, M. Siaj, and F. Larachi, "CO2 capture in alkanolamine/roomtemperature ionic liquid emulsions: A viable approach with carbamate crystallization and curbed corrosion behavior," Int. J. Greenh. Gas Control, vol. 6, pp. 246-252, Jan. 2012.

[6] S. Satyapal, T. Filburn, J. Trela, and J. Strange, "Performance and Properties of a Solid Amine Sorbent for Carbon Dioxide Removal in Space Life Support Applications," Energy Fuels, vol. 15, no. 2, pp. 250-255, Mar. 2001.

[7] L. Zhou, "Progress and problems in hydrogen storage methods," Renew. Sustain. Energy Rev., vol. 9, no. 4, pp. 395-408, Aug. 2005.

[8] O. Ioannidou and A. Zabaniotou, "Agricultural residues as precursors for activated carbon production-A review," Renew. Sustain. Energy Rev., vol. 11, no. 9, pp. 19662005, Dec. 2007.

[9] M. G. Plaza, C. Pevida, B. Arias, J. Fermoso, F. Rubiera, and J. J. Pis, “A comparison of two methods for producing CO2 capture adsorbents," Energy Procedia, vol. 1, no. 1, pp. 1107-1113, Feb. 2009.

[10] M. G. Plaza, C. Pevida, C. F. Martín, J. Fermoso, J. J. Pis, and F. Rubiera, "Developing almond shell-derived activated carbons as CO2 adsorbents," Sep. Purif. Technol., vol. 71, no. 1, pp. 102-106, Jan. 2010.

[11] M. G. Plaza et al., "Development of low-cost biomass-based adsorbents for postcombustion CO2 capture," Fuel, vol. 88, no. 12, pp. 2442-2447, Dec. 2009.

[12] M. Plaza et al., "Different Approaches for the Development of Low-Cost CO2 Adsorbents," J. Environ. Eng., vol. 135, no. 6, pp. 426-432, Mar. 2009.

[13] H. Jin, Y. S. Lee, and I. Hong, "Hydrogen adsorption characteristics of activated carbon," Catal. Today, vol. 120, no. 3-4, pp. 399-406, Feb. 2007.

[14] M. Zyzlila Figueroa-Torres, A. Robau-Sánchez, L. De la Torre-Sáenz, and A. AguilarElguézabal, "Hydrogen adsorption by nanostructured carbons synthesized by chemical activation," Microporous Mesoporous Mater., vol. 98, no. 1-3, pp. 89-93, Jan. 2007. 
[15] H. Akasaka et al., "Hydrogen storage ability of porous carbon material fabricated from coffee bean wastes," Int. J. Hydrog. Energy, vol. 36, no. 1, pp. 580-585, Jan. 2011.

[16] D. Wang, Z. Geng, C. Zhang, X. Zhou, and X. Liu, "Effects of thermal activation conditions on the microstructure regulation of corncob-derived activated carbon for hydrogen storage," J. Energy Chem., vol. 23, no. 5, pp. 601-608, Sep. 2014.

[17] J. Wang, I. Senkovska, S. Kaskel, and Q. Liu, "Chemically activated fungi-based porous carbons for hydrogen storage," Carbon, vol. 75, pp. 372-380, Aug. 2014.

[18] "La Production." [Online]. Available: http://www.onh.com.tn/index.php/fr/2016-05-2314-44-46/la-production. [Accessed: 10-Nov-2016].

[19] D. Cazorla-Amorós, J. Alcañiz-Monge, M. A. de la Casa-Lillo, and A. Linares-Solano, "CO2 As an Adsorptive To Characterize Carbon Molecular Sieves and Activated Carbons," Langmuir, vol. 14, no. 16, pp. 4589-4596, Aug. 1998.

[20] M. M. Dubinin, "Fundamentals of the theory of adsorption in micropores of carbon adsorbents: Characteristics of their adsorption properties and microporous structures," Carbon, vol. 27, no. 3, pp. 457-467, Jan. 1989.

[21] F. Stoeckli and L. Ballerini, "Evolution of microporosity during activation of carbon," Fuel, vol. 70, no. 4, pp. 557-559, Apr. 1991.

[22] S. Loganathan, M. Tikmani, S. Edubilli, A. Mishra, and A. K. Ghoshal, "CO2 adsorption kinetics on mesoporous silica under wide range of pressure and temperature," Chem. Eng. J., vol. 256, pp. 1-8, Nov. 2014.

[23] M. Molina-Sabio and F. Rodríguez-Reinoso, "Role of chemical activation in the development of carbon porosity," Colloids Surf. Physicochem. Eng. Asp., vol. 241, no. 1-3, pp. 15-25, Jul. 2004.

[24] H. Marsh, D. S. Yan, T. M. O'Grady, and A. Wennerberg, "Formation of active carbons from cokes using potassium hydroxide," Carbon, vol. 22, no. 6, pp. 603-611, Jan. 1984.

[25] T. Otowa, R. Tanibata, and M. Itoh, "Production and adsorption characteristics of MAXSORB: High-surface-area active carbon,” Gas Sep. Purif., vol. 7, no. 4, pp. 241245, Jan. 1993.

[26] M. G. Plaza, A. S. González, C. Pevida, J. J. Pis, and F. Rubiera, "Valorisation of spent coffee grounds as CO2 adsorbents for postcombustion capture applications," Appl. Energy, vol. 99, pp. 272-279, Nov. 2012.

[27] J.-S. Bae and S. Su, "Macadamia nut shell-derived carbon composites for post combustion CO2 capture," Int. J. Greenh. Gas Control, vol. 19, pp. 174-182, Nov. 2013.

[28] Z. Xiong, Z. Shihong, Y. Haiping, S. Tao, C. Yingquan, and C. Hanping, "Influence of NH3/CO2 Modification on the Characteristic of Biochar and the CO2 Capture," BioEnergy Res., vol. 6, no. 4, pp. 1147-1153, Feb. 2013.

[29] N. A. Rashidi, S. Yusup, A. Borhan, and L. H. Loong, "Experimental and modelling studies of carbon dioxide adsorption by porous biomass derived activated carbon," Clean Technol. Environ. Policy, vol. 16, no. 7, pp. 1353-1361, May 2014.

[30] M. G. Plaza, A. S. González, J. J. Pis, F. Rubiera, and C. Pevida, "Production of microporous biochars by single-step oxidation: Effect of activation conditions on $\mathrm{CO} 2$ capture," Appl. Energy, vol. 114, pp. 551-562, Feb. 2014.

[31] M. G. Plaza, A. S. González, C. Pevida, and F. Rubiera, "Green coffee based CO2 adsorbent with high performance in postcombustion conditions," Fuel, vol. 140, pp. 633-648, Jan. 2015.

[32] R. Azargohar and A. K. Dalai, "Steam and KOH activation of biochar: Experimental and modeling studies," Microporous Mesoporous Mater., vol. 110, no. 2-3, pp. 413-421, Apr. 2008. 
[33] Y. Sudaryanto, S. B. Hartono, W. Irawaty, H. Hindarso, and S. Ismadji, "High surface area activated carbon prepared from cassava peel by chemical activation," Bioresour. Technol., vol. 97, no. 5, pp. 734-739, Mar. 2006.

[34] J. Wang, A. Heerwig, M. R. Lohe, M. Oschatz, L. Borchardt, and S. Kaskel, "Fungibased porous carbons for CO2 adsorption and separation," J. Mater. Chem., vol. 22, no. 28, pp. 13911-13913, Jun. 2012.

[35] S. Lowell and J. E. Shields, Powder Surface Area and Porosity. Dordrecht: Springer Netherlands, 1991.

[36] H. W. Langmi et al., "Hydrogen adsorption in zeolites A, X, Y and RHO," J. Alloys Compd., vol. 356-357, pp. 710-715, Aug. 2003.

[37] H. W. Langmi et al., "Hydrogen storage in ion-exchanged zeolites," J. Alloys Compd., vol. 404-406, pp. 637-642, Dec. 2005.

[38] S. S. Kaye and J. R. Long, "Hydrogen Storage in the Dehydrated Prussian Blue Analogues M3[Co(CN)6]2 (M = Mn, Fe, Co, Ni, Cu, Zn)," J. Am. Chem. Soc., vol. 127, no. 18, pp. 6506-6507, May 2005.

[39] S. Yuan, S. Kirklin, B. Dorney, D.-J. Liu, and L. Yu, "Nanoporous Polymers Containing Stereocontorted Cores for Hydrogen Storage," Macromolecules, vol. 42, no. 5, pp. 1554-1559, Mar. 2009.

[40] J. Germain, J. Hradil, J. M. J. Fréchet, and F. Svec, "High Surface Area Nanoporous Polymers for Reversible Hydrogen Storage," Chem. Mater., vol. 18, no. 18, pp. 44304435, Sep. 2006.

[41] J. Ren, H. W. Langmi, B. C. North, M. Mathe, and D. Bessarabov, "Modulated synthesis of zirconium-metal organic framework (Zr-MOF) for hydrogen storage applications," Int. J. Hydrog. Energy, vol. 39, no. 2, pp. 890-895, Jan. 2014.

[42] J. Ren et al., "Modulated synthesis of chromium-based metal-organic framework (MIL101) with enhanced hydrogen uptake," Int. J. Hydrog. Energy, vol. 39, no. 23, pp. 12018-12023, Aug. 2014.

[43] J. Ren et al., "Hydrogen storage in Zr-fumarate MOF," Int. J. Hydrog. Energy, vol. 40, no. 33, pp. 10542-10546, Sep. 2015.

[44] N. M. Musyoka, J. Ren, H. W. Langmi, B. C. North, and M. Mathe, "A comparison of hydrogen storage capacity of commercial and fly ash-derived zeolite $\mathrm{X}$ together with their respective templated carbon derivatives," Int. J. Hydrog. Energy, vol. 40, no. 37, pp. 12705-12712, Oct. 2015.

[45] H. Wang, Q. Gao, and J. Hu, "High Hydrogen Storage Capacity of Porous Carbons Prepared by Using Activated Carbon," J. Am. Chem. Soc., vol. 131, no. 20, pp. 70167022, May 2009.

[46] N. Texier-Mandoki, J. Dentzer, T. Piquero, S. Saadallah, P. David, and C. Vix-Guterl, "Hydrogen storage in activated carbon materials: Role of the nanoporous texture," Carbon, vol. 42, no. 12-13, pp. 2744-2747, 2004.

[47] M. Kunowsky, J. P. Marco-Lozar, A. Oya, and A. Linares-Solano, "Hydrogen storage in CO2-activated amorphous nanofibers and their monoliths," Carbon, vol. 50, no. 3, pp. 1407-1416, Mar. 2012.

[48] P. A. Georgiev, D. K. Ross, P. Albers, and A. J. Ramirez-Cuesta, "The rotational and translational dynamics of molecular hydrogen physisorbed in activated carbon: A direct probe of microporosity and hydrogen storage performance," Carbon, vol. 44, no. 13, pp. 2724-2738, Nov. 2006.

[49] Celzard, Fierro, Marêché, and Furdin, “Advanced Preparative Strategies for Activated Carbons Designed for the Adsorptive Storage of Hydrogen," Adsorpt. Sci. Technol., vol. 25, no. 3, pp. 129-142, Apr. 2007. 
[50] S. Patchkovskii, J. S. Tse, S. N. Yurchenko, L. Zhechkov, T. Heine, and G. Seifert, "Graphene nanostructures as tunable storage media for molecular hydrogen," Proc. Natl. Acad. Sci. U. S. A., vol. 102, no. 30, pp. 10439-10444, Jul. 2005.

[51] M. Rzepka, P. Lamp, and M. A. de la Casa-Lillo, "Physisorption of Hydrogen on Microporous Carbon and Carbon Nanotubes," J. Phys. Chem. B, vol. 102, no. 52, pp. 10894-10898, Dec. 1998.

[52] L. Zhou, Y. Zhou, and Y. Sun, "Enhanced storage of hydrogen at the temperature of liquid nitrogen," Int. J. Hydrog. Energy, vol. 29, no. 3, pp. 319-322, Mar. 2004.

[53] G. Zini, R. Marazzi, S. Pedrazzi, and P. Tartarini, "A solar hydrogen hybrid system with activated carbon storage," Int. J. Hydrog. Energy, vol. 35, no. 10, pp. 4909-4917, May 2010.

[54] G. Zini and P. Tartarini, "Wind-hydrogen energy stand-alone system with carbon storage: Modeling and simulation," Renew. Energy, vol. 35, no. 11, pp. 2461-2467, Nov. 2010.

[55] V. Presser, J. McDonough, S.-H. Yeon, and Y. Gogotsi, "Effect of pore size on carbon dioxide sorption by carbide derived carbon," Energy Environ. Sci., vol. 4, no. 8, p. 3059, 2011.

[56] M. Cinke, J. Li, C. W. Bauschlicher Jr., A. Ricca, and M. Meyyappan, "CO2 adsorption in single-walled carbon nanotubes," Chem. Phys. Lett., vol. 376, no. 5-6, pp. 761-766, Jul. 2003.

[57] P. I. Ravikovitch and A. V. Neimark, "Diffusion-Controlled Hysteresis," Adsorption, vol. 11, no. 1, pp. 265-270.

[58] M. C. Blanco López, A. Martínez-Alonso, and J. M. D. Tascón, "N2 and CO2 adsorption on activated carbon fibres prepared from Nomex chars," Carbon, vol. 38, no. 8, pp. 1177-1182, 2000.

[59] D. P. Vargas, L. Giraldo, A. Erto, and J. C. Moreno-Piraján, "Chemical modification of activated carbon monoliths for $\mathrm{CO} 2$ adsorption," J. Therm. Anal. Calorim., vol. 114, no. 3, pp. 1039-1047, Apr. 2013.

[60] D. P. Vargas, L. Giraldo, and J. C. Moreno-Piraján, "CO2 adsorption on granular and monolith carbonaceous materials," J. Anal. Appl. Pyrolysis, vol. 96, pp. 146-152, Jul. 2012.

[61] A. S. Ello, L. K. C. de Souza, A. Trokourey, and M. Jaroniec, "Coconut shell-based microporous carbons for CO2 capture," Microporous Mesoporous Mater., vol. 180, pp. 280-283, Nov. 2013.

[62] Z. Zhang et al., "Sustainable and hierarchical porous Enteromorpha prolifera based carbon for CO2 capture," J. Hazard. Mater., vol. 229-230, pp. 183-191, Aug. 2012.

[63] M. Sevilla and A. B. Fuertes, "Sustainable porous carbons with a superior performance for CO2 capture,” Energy Environ. Sci., vol. 4, no. 5, pp. 1765-1771, Apr. 2011.

[64] R. Wang, P. Wang, X. Yan, J. Lang, C. Peng, and Q. Xue, "Promising Porous Carbon Derived from Celtuce Leaves with Outstanding Supercapacitance and CO2 Capture Performance," ACS Appl. Mater. Interfaces, vol. 4, no. 11, pp. 5800-5806, Nov. 2012.

[65] G. K. Parshetti, S. Chowdhury, and R. Balasubramanian, "Biomass derived low-cost microporous adsorbents for efficient CO2 capture,” Fuel, vol. 148, pp. 246-254, May 2015.

[66] M. S. Shafeeyan, W. M. A. Wan Daud, A. Houshmand, and A. Arami-Niya, "The application of response surface methodology to optimize the amination of activated carbon for the preparation of carbon dioxide adsorbents," Fuel, vol. 94, pp. 465-472, Apr. 2012. 
[67] M. G. Plaza, I. Durán, F. Rubiera, and C. Pevida, "CO2 adsorbent pellets produced from pine sawdust: Effect of coal tar pitch addition,” Appl. Energy, vol. 144, pp. 182-192, Apr. 2015.

[68] M. G. Plaza, C. Pevida, A. Arenillas, F. Rubiera, and J. J. Pis, "CO2 capture by adsorption with nitrogen enriched carbons," Fuel, vol. 86, no. 14, pp. 2204-2212, Sep. 2007.

[69] C. F. Martín, M. G. Plaza, J. J. Pis, F. Rubiera, C. Pevida, and T. A. Centeno, "On the limits of CO2 capture capacity of carbons," Sep. Purif. Technol., vol. 74, no. 2, pp. 225 229, Aug. 2010.

[70] M. M. Maroto-Valer, Z. Tang, and Y. Zhang, "CO2 capture by activated and impregnated anthracites," Fuel Process. Technol., vol. 86, no. 14-15, pp. 1487-1502, Oct. 2005. 


\section{Figures}

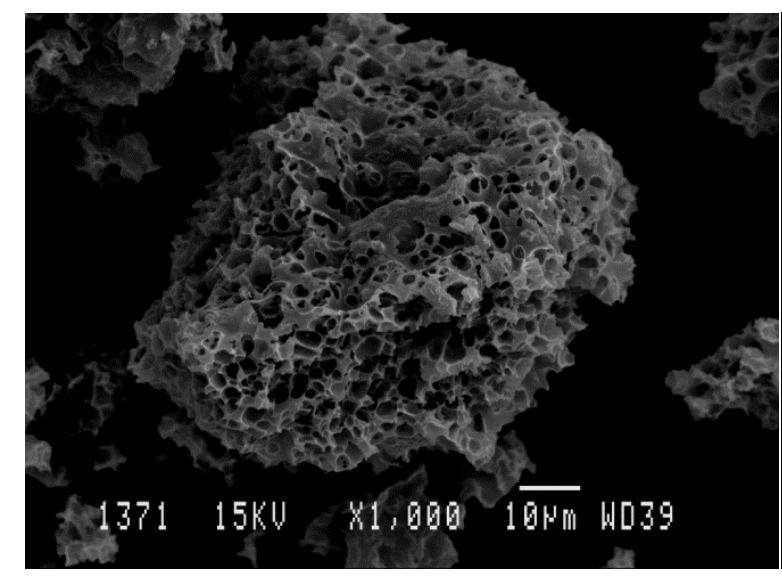

(a)

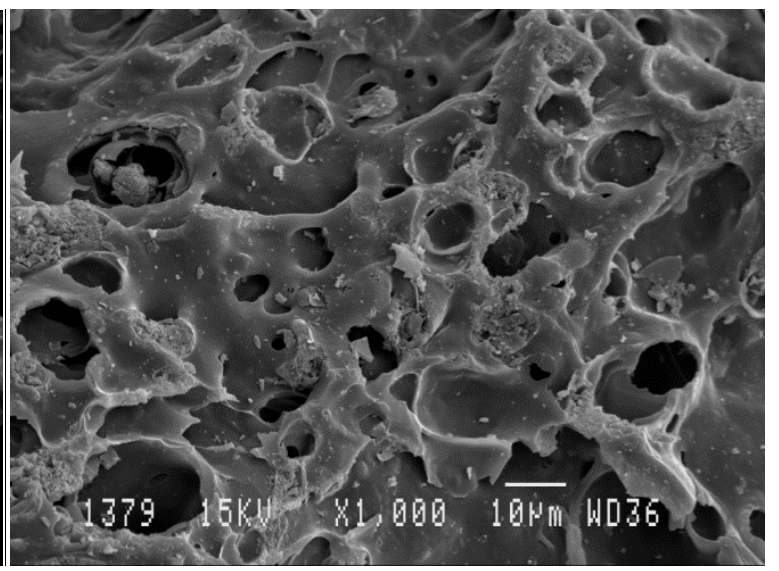

(b)

Figure 1. SEM micrographs of $A C \_K O H ~(a)$ and $A C \_K_{2} C_{3}$ (b) 


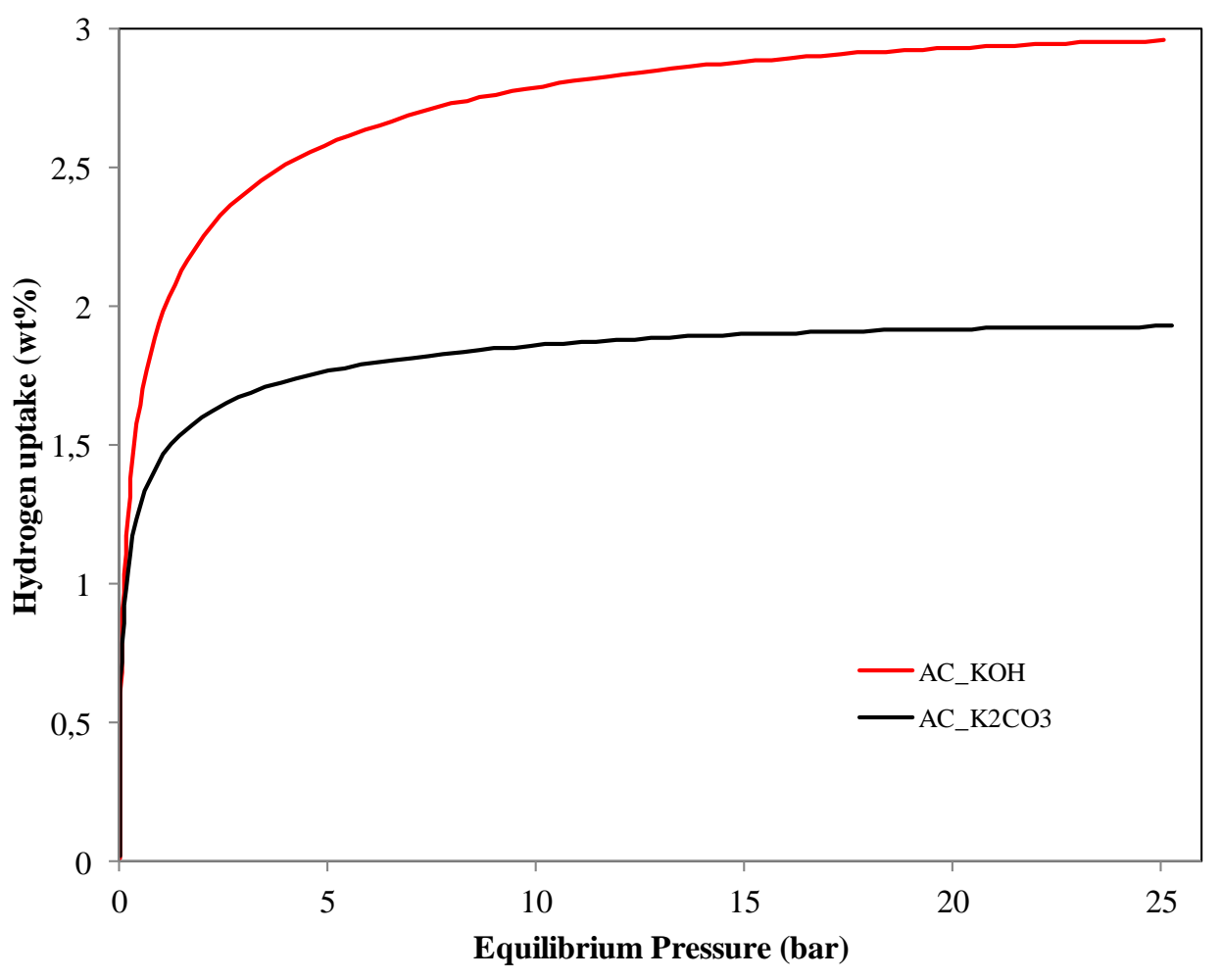

(a)

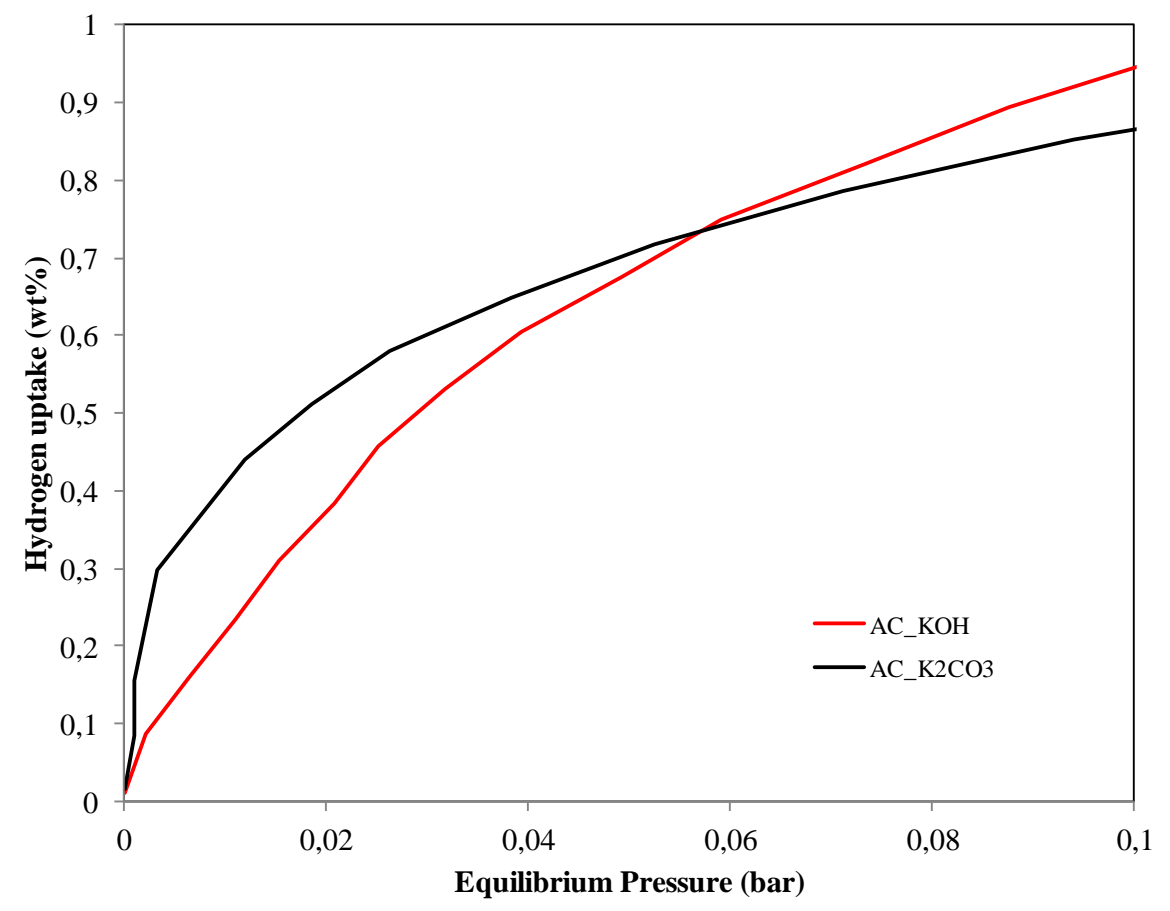

(b)

Figure 2. Excess hydrogen adsorption isotherms at $-196^{\circ} \mathrm{C}$ and up to 25 bar (a) and at subatmopheric pressure (b) 


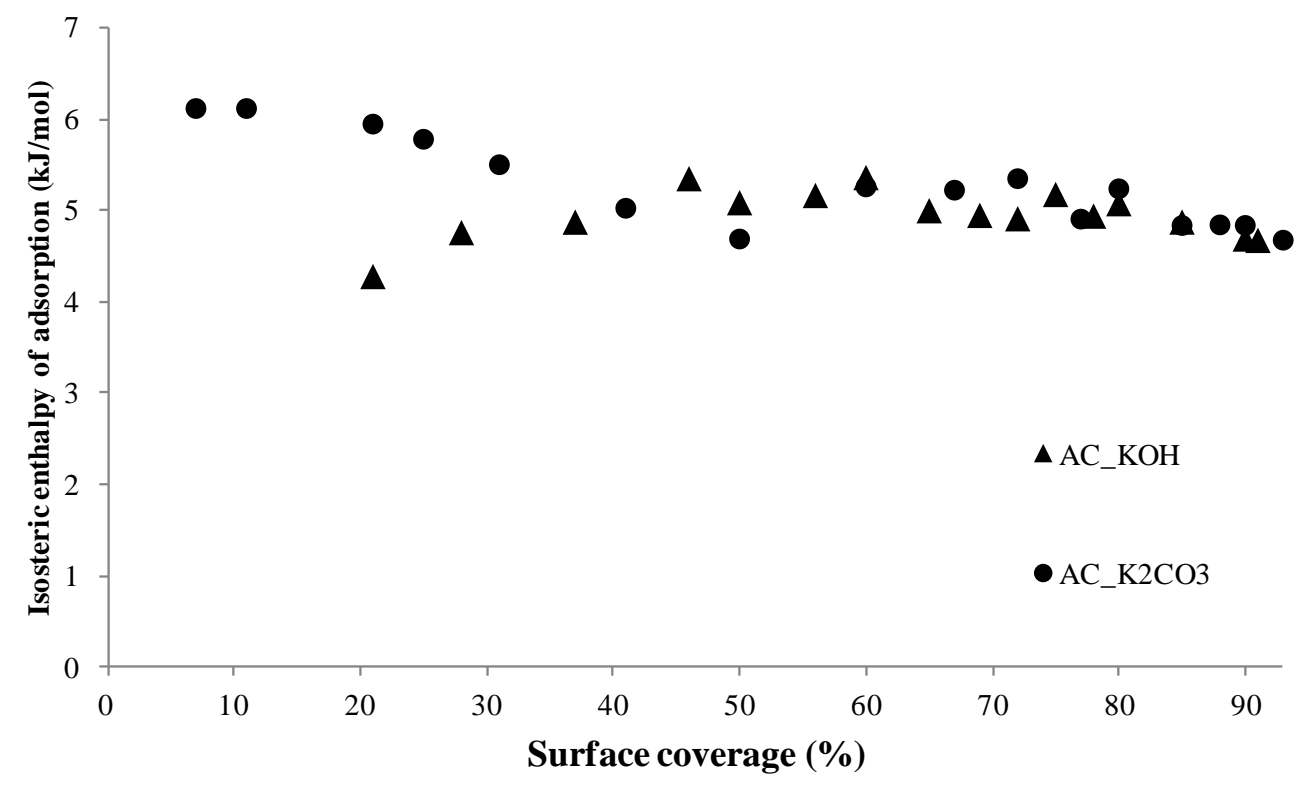

Figure 3. Isosteric heat of adsorption of $\mathrm{H}_{2}$ in activated carbons versus the carbon surface coverage 


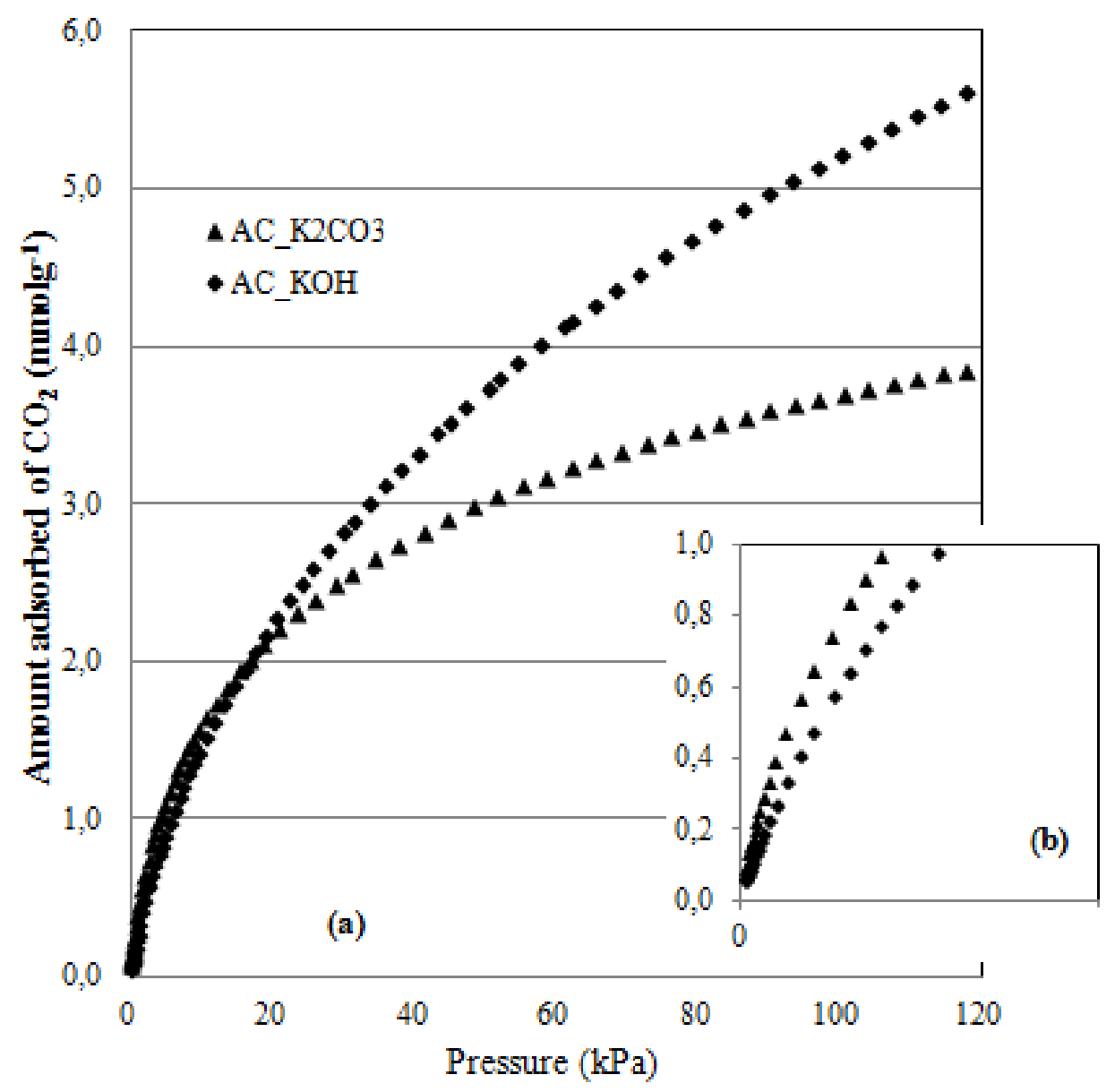

Figure 4. $\mathrm{CO}_{2}$ adsorption on olive stones-based activated carbons at $0^{\circ} \mathrm{C}$ 


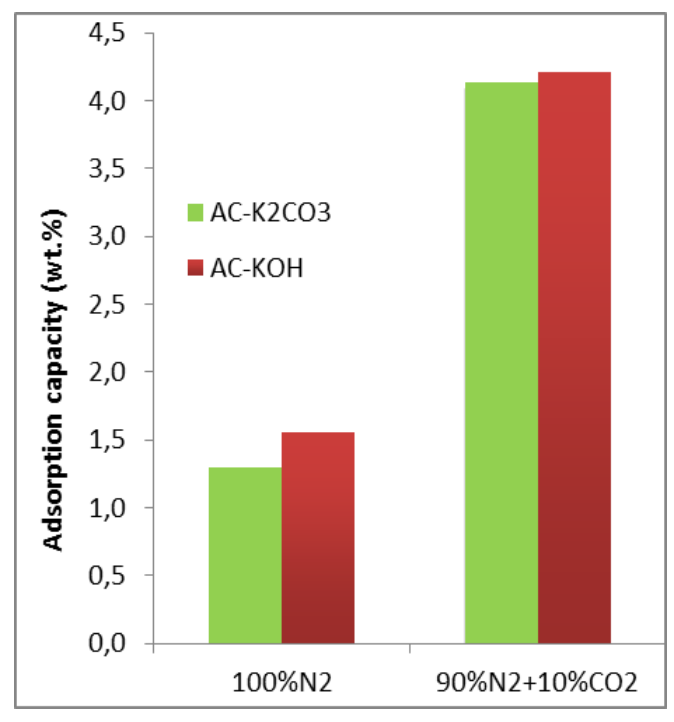

(a)

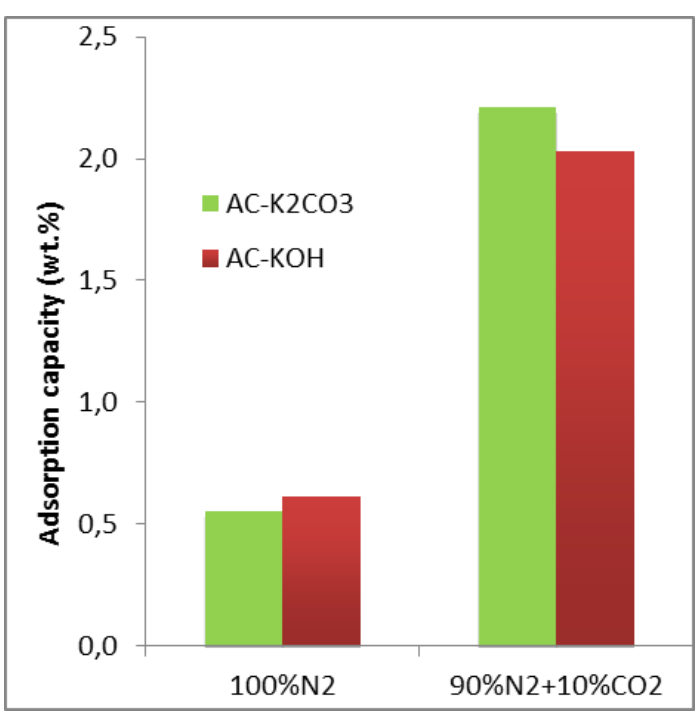

(b)

Figure5. Equilibrium adsorption capacity of the two prepared carbons in a mixture consisting of $10 \% \mathrm{CO}_{2}$ (balance $\mathrm{N}_{2}$ ) expressed on a mass basis, at atmospheric pressure: (a) at $25^{\circ} \mathrm{C}$, (b) at $50^{\circ} \mathrm{C}$.

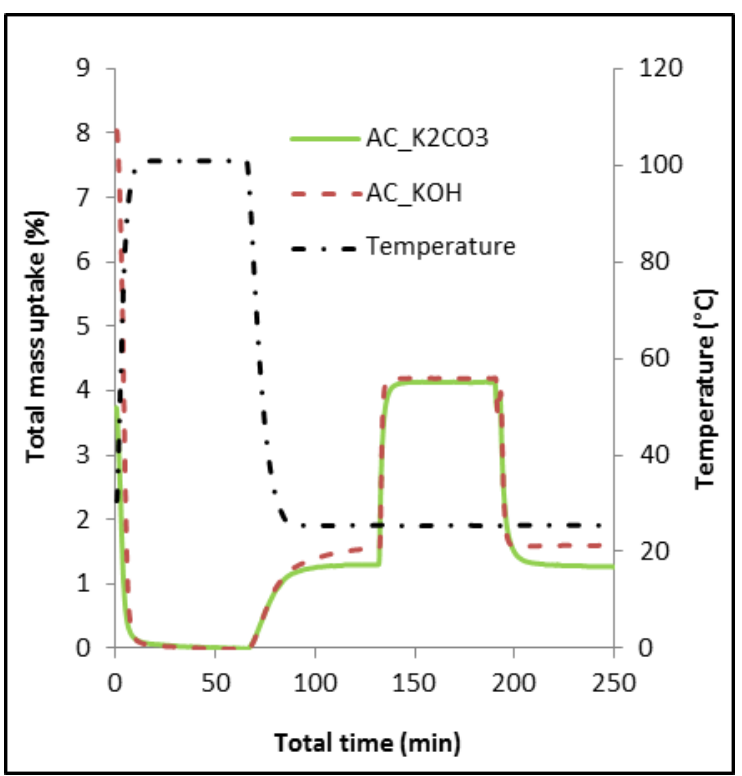

(a)

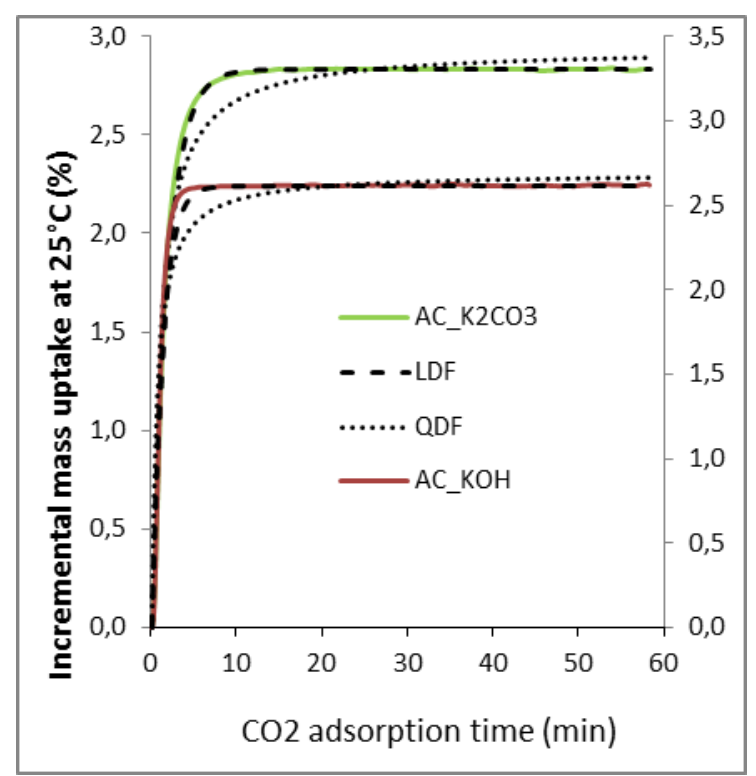

(b)

Figure 6 The adsorption performance of the two prepared activated carbon at $25^{\circ} \mathrm{C}$ : (a) total mass uptake vs.time (full experiment); (b) incremental mass uptake of $10 \% \mathrm{CO}_{2}$ (balance $\mathrm{N} 2$ ). 


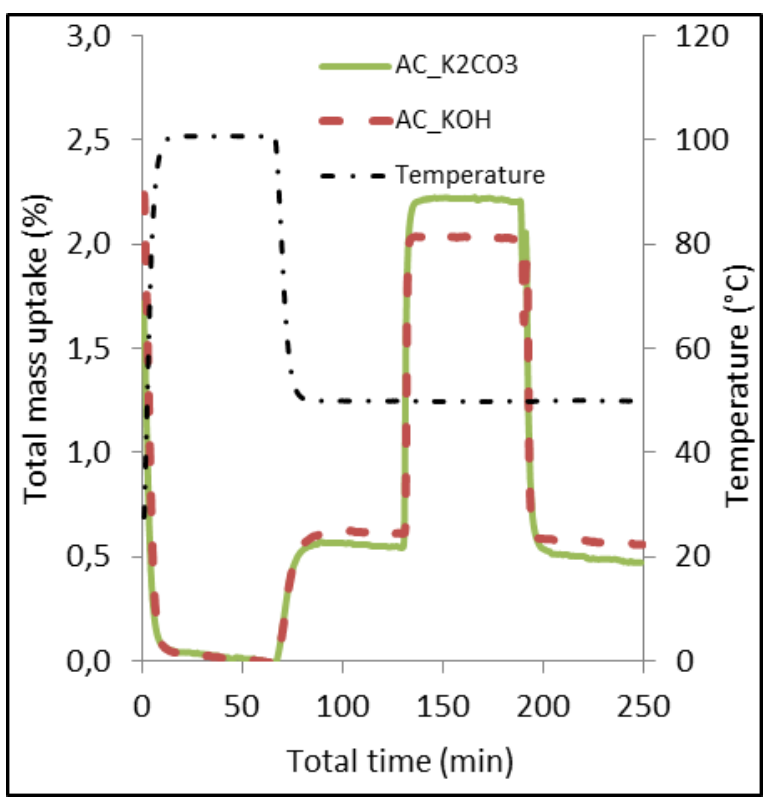

(a)

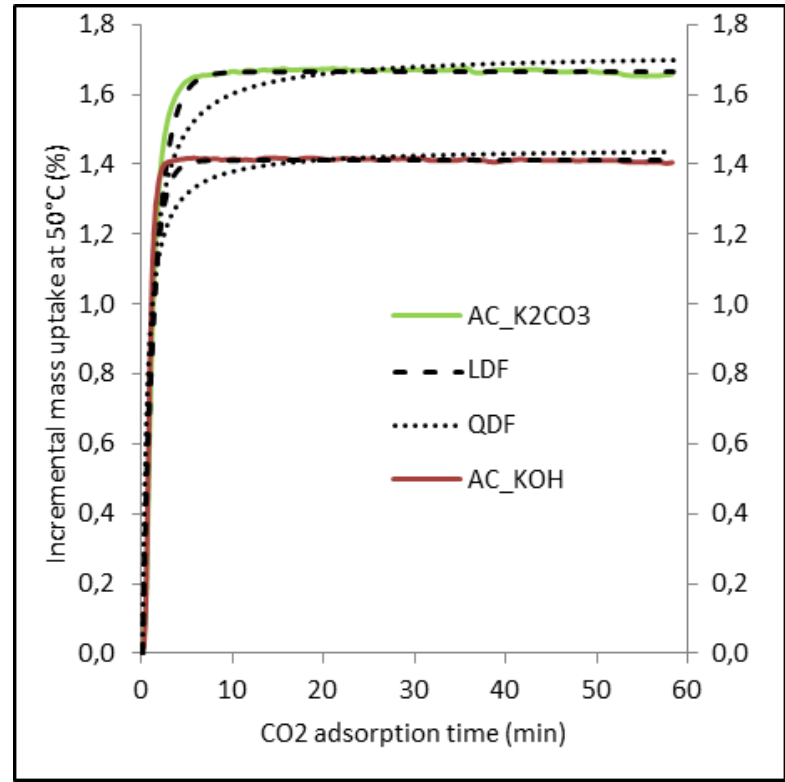

(b)

Figure 7 The adsorption performance of the two prepared activated carbon at $50^{\circ} \mathrm{C}$ : (a) total mass uptake vs.time (full experiment) ; (b) incremental mass uptake of $10 \% \mathrm{CO}_{2}$ (balance $\mathrm{N}_{2}$ ). 